\title{
RETRACTION
}

The Journal of Veterinary Medical Science

\section{Topography of Retinal Ganglion Cells in the Dromedary Camel}

\section{(Camelus dromedarius)}

Mohamed $\mathrm{ABDO}^{1{ }^{12} \text { ), }}$, Khaled SHOGHY ${ }^{2)}$, Yoshinao Z. HOSAKA ${ }^{1)}$, Tomohiro IMAGAWA ${ }^{1)}$, Safwat $\mathrm{ALI}^{2)}$, Atef ERASHA ${ }^{2)}$, Masato UEHARA ${ }^{1)}$

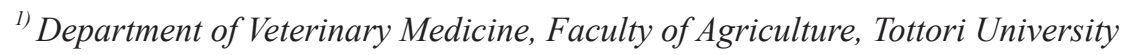

2) Department of Anatomy and Embryology, Faculty of Veterinary Medicine, Sadat City University

This article has been retracted by the Editorial Board of Journal of Veterinary Medical Science due to a violation of the journal's "Information for Authors".

The Journal of Veterinary Medical Science

DOI: $10.1292 /$ jvms.14-0225 